\title{
Screening for Resistance against Rhizoctonia bataticola Causing Dry Root-Rot in Chickpea (Cicer arietinum L.)
}

\author{
P. Wagh* , N. Khare and R. K. Dantre \\ Department of Plant pathology, I.G.K.V. Raipur, (C.G.), India \\ *Corresponding author
}

\section{A B S T R A C T}

\section{Keywords}

Cicer arietinum, Dry root rot, Rhizoctonia bataticola, Screening, Resistance

Article Info

Accepted:

20 May 2018

Available Online:

10 June 2018
Chickpea dry root rot is caused by Rhizoctonia bataticola is the most destructive disease and causes severe losses in yield. Therefore, the present investigation were undertaken to screen different genotypes for their resistance to dry root rot. One hundred twenty seven chickpea genotypes were evaluated for locating new and better sources of resistance against dry root rot through disease sick fields at IGKV, Raipur during 2012 to 2013. Desi III only one entry was found moderately resistant (BG 3033), while three entries NDG 1112, RKG 202022 and H 09-90 were tolerant. Whereas, in rainfed (R.F. II) sets of entries, Phule G 0752 was exhibited moderately resistant and JG 33 and CSJ 741 were tolerant. Three entries namely, RSG 9056, JG 16 and CSJ 8023 were found tolerant in elites lines. 100 per cent mortality was observed in the susceptible check (L-550) indicating the high and uniform sickness in the soil. The genotypes identified as resistant are of great value and may be exploited in breeding programme for developing high yielding resistant varieties.

\section{Introduction}

Gram or Chickpea (Cicer arietinum Linnaeus), a member of family Fabaceae, is an ancient self-pollinated leguminous crop, diploid annual ( $2 \mathrm{~N}=16$ chromosomes) grown since, $7000 \mathrm{BC}$, in different area of the world. Chickpea (Cicer arietinum L.) originated in South Eastern Turkey Asia. It was grown on about 11.9 million hectares at globe in 2010 . Chickpea production has increased over the past 30 years from 6.6 million metric tons to 10.0 million metric tons. Most chickpeas are grown in South Asia, which accounts for more than $75 \%$ of the world chickpea area. India is by far the largest chickpea producing country, the area under chickpea in India increased marginally to 7.9 million hectares, with production 6.8 million metric tons (2010). A total chickpea area increased from $329.28 \mathrm{mha}$ to 803.03 mha in C.G. $(45.06 \%)$ in $2011-12$.

Diseases are the most serious constraints to chickpea productivity causing up to $100 \%$ losses. Environmental factors and intensity of abiotic stresses are known to compound the occurrence and severity of the diseases.

The crop is vulnerable to number of diseases. The chickpea crop is attacked by 172 pathogens (67 fungi, 22 viruses, 3 bacteria, 80 nematodes and mycoplasma) from all over the 
world (Nene et al., 1996) Among all, only a few of them have the potential to devastate the crops. Some of the serious diseases in order of their importance are wilt (Fusarium oxysporum f.sp. ciceri), dry root rot (Rhizoctonia bataticola), collar rot (Sclerotium rolfsii), wet root rot (Rhizoctonia solani), ascochyta blight (Ascochyta rabiae), botrytis grey mould (Botrytis cinerea) and chickpea stunt. Among the several soil borne fungal diseases of chickpea, dry root rot caused by Rhizoctonia bataticola Taub (Butler) is the most severe diseases particularly in the central and southern zone, where the crop is mostly grown under rainfed.

Disease generally appears around flowering and podding stage. The first symptom is yellowing and sudden drying of the plants. The tap root becomes dark brown quite brittle in dry soil and shows extensive rotting resulting in the loss of lateral roots. The lower portion of the tap root is often left in the soil when plant is uprooted. The most ideal and economical way of controlling this disease is the use of host resistance which can be determined by different germplasm screening techniques viz., screening of germplasm.

\section{Materials and Methods}

Chickpea dry root rot infected plants were collected from field of I.G.KV., Raipur and the isolations were made from roots showing characteristics symptoms of disease. The purified culture of Rhizoctonia bataticola was maintained on PDA slants for screening the germplasms line.

The fungus was then multiplied in sand + maize medium by inoculating with $10 \mathrm{~mm}$ PDA disc of $R$. bataticola at $28^{\circ} \mathrm{C}$ for 15 days. In screening, 127 accessions of the desi and kabuli chickpea genotypes were evaluated against dry root rot in field during Rabi season 2012-2013.

\section{Field screening}

Culture of $R$. bataticola was artificially inoculated near root zone. Row of each replication was inoculated. Light irrigation was given just to activate the growth of fungus. First observations were recorded 20 days after sowing and second on 7 days after inoculation on the basis of motality. Each test entry was sown in a plot of two rows of 5 meter length at $30 \mathrm{~cm}$ apart with one row of susceptible check L 550 after every two test entry and replicated twice in randomized block design. Observations on emergence count were recorded at 20 DAS and per cent mortality due to $R$. bataticola recorded at 20 days interval up to maturity of the crop plant and finally computed as follows:

Number of diseased plants

Per cent mortality = ---------------------- X 100

Total number of plants

\section{Results and Discussion}

The present study, indicate out of 127 entries, 3 is moderately resistance and 8 entries were tolerant.

Desi III only one entry was found moderately resistant (BG 3033), while three entries NDG 11-12, RKG 202022 and H 09-90 were tolerant. Whereas, in rainfed (R.F. II) sets of entries, Phule G 0752 was exhibited moderately resistant and JG 33 and CSJ 741 were tolerant. Three entries namely, RSG 9056, JG 16 and CSJ 8023 were found tolerant in elites lines. However, remaining all the entries in Desi I, Desi II, late sown I, late sown II and Rainfed I were showed susceptible and highly susceptible to dry root rot.

100 per cent mortality was observed in the susceptible check (L-550) indicating the high and uniform sickness in the soil. 
Table.1 Screening of chickpea entries against dry root rot

\begin{tabular}{|c|c|c|c|c|c|c|c|c|c|}
\hline \multirow[t]{2}{*}{$\%$ Mortality } & \multirow{2}{*}{$\begin{array}{l}\text { Score } \\
\text { Reaction }\end{array}$} & \multicolumn{8}{|c|}{ Entries } \\
\hline & & $\begin{array}{c}\text { Desi I } \\
\text { AVT }\end{array}$ & $\begin{array}{c}\text { Desi II } \\
\text { AVT }\end{array}$ & $\begin{array}{l}\text { Desi III } \\
\text { IVT }\end{array}$ & $\begin{array}{l}\text { LS I } \\
\text { AVT }\end{array}$ & $\begin{array}{l}\text { LSII } \\
\text { IVT }\end{array}$ & $\begin{array}{l}\text { RF I } \\
\text { AVT }\end{array}$ & $\begin{array}{l}\text { RFII } \\
\text { IVT }\end{array}$ & Elites \\
\hline Less than $10 \%$ & $1(\mathrm{R})$ & 0 & 0 & 0 & 0 & 0 & 0 & 0 & 0 \\
\hline $10-20 \%$ & 2 (MR) & 0 & 0 & 1 & 0 & 0 & 0 & 1 & 0 \\
\hline $20-30 \%$ & $3(\mathrm{~T})$ & 0 & 0 & 3 & 0 & 0 & 0 & 2 & 3 \\
\hline $30-50 \%$ & $4(S)$ & 4 & 4 & 15 & 5 & 20 & 7 & 11 & 10 \\
\hline Above $\mathbf{5 0 \%}$ & $5(\mathrm{HS})$ & 3 & 3 & 10 & 5 & 6 & 3 & 10 & 1 \\
\hline Total entries & & 7 & 7 & 29 & 10 & 26 & 10 & 24 & 14 \\
\hline L.S.I. (\%) & & 4.42 & 4.42 & 4.17 & 4.50 & 4.23 & 4.30 & 4.25 & 3.85 \\
\hline
\end{tabular}

LS: Late Sown, RF: Rainfed, Elites: National nursery elite lines, LSI: Location severity index

Similar findings have been reported (Jayalakshami etal, 2008) Chickpea genotypes have been screened and identified as resistant to dry root rot by various workers on the basis of in vitro and field conditions (Nene et al., 1981, Anand Rao and Haware, 1987, Reddy et al., 1990, Bhatt, 1993, Gupta, 1997, Khalid and Ilyas, 2000 and Gupta et al., 2006).

In present experiment, out of 127 entries, 8 entries were tolerant whereas, Gupta et al., (2012) evaluated 170 germplasm in vitro condition and further evaluation of 26 promising lines under disease sick field, it was found that six lines viz., JG 2000-07, JSC 37, MPJG 89-11551, MPJG 89-9023, CSJ 592 and Rajas were resistant, exhibiting $<10$ per cent mortality, however 14 lines showed moderately resistant reaction (JG 2003-14-16, JG 2001-12, JG 315, MPJG 2001-04, H02-14, CSJ 556, CSJ 558, GNG 1488, PG01108, HK- 02-201, HK 03-45, HK 03113, WCG 2000-07 and IPC 2005-28) against $R$. bataticola during the testing years (20072010) under high disease pressure.

Gangwar et al., (2002) screened 35 chickpea cultivars for resistance to dry root rot in a field experiment, only 10 cultivars (ICC 2644, 10384, 10630, 112244, 11332, ICCL 81002, 810810, ICC 12263, 12441 and ICCV 90254) were found resistant however, Phule G 9504, 96020, 96105, 96313 and GL 91059 were moderately resistant.

\section{References}

Anand Rao P.K. and Haware M.P. 1987. Inheritance of dry root-rot Rhizoctonia bataticola resistance in chickpea. Plant Breeding 98:349-352.

Bhatt J. 1993. Reaction of chickpea cultivars of Rhizoctonia bataticola (Taub) Butler (Macrophomina phaseolina) (Tassi) Goid. Indian Journal of Pulses Research 6: 118-119.

Gangwar R.K., Prajapti R.K., Shrivastava S.S.L., Kumar Kumud and Kumar K. 2002. Resistance in chickpea germplasms against dry root rot. Annals of Plant Protection Sciences 10: 393394.

Gupta Om and Babbar A. 2006. Identification of desi and kabuli chickpea genotypes for multiple disease resistance against soil borne disease. Indian Journal of Pulses Research. 19: 129-130.

Gupta Om. 1997. Occurrence of combined resistance to wilt and dry root rot in chickpea. Indian Journal of Pulses Research 10: 125-126.

Jayalakshmi S.K., S. Usharani, V.I. Benagi and D.M. Mannu, 2008. Source of 
resistance to dry root rot of chickpea caused by Rhizoctonia bataticola. Agri.Sci.digest 28 (2): 147-148, 2008

Khalid Iftikhar and Ilyas M.B. 2000. Screening of chickpea germplasm against dry root rot disease (Macrophomina phaseolina) in pots/glass house. Pakistan Journal of Phytopathology 12: 66-70.

Nene Y.L., Haware M.P. and Reddy M.V. 1981. Chickpea disease resistance screening techniques. Information Bulletin ICRISAT 10: 10-11.

Om Gupta, Manisha Rathi and Madhuri Mishra. 2012. Screening for resistance against Rhizoctonia bataticola causing dry root-rot in chickpea. Journal of Food Legumes 25(2): 139-141.

Reddy M.V., Raju R.N. and Pundir R.P.S. 1990. Additional sources of resistance to wilt and root rot in chickpea. International Chickpea Newsletter 22: $36-38$.

\section{How to cite this article:}

Wagh P., N. Khare and Dantre R. K. 2018. Screening for Resistance against Rhizoctonia bataticola Causing Dry Root-Rot in Chickpea (Cicer arietinum L.). Int.J.Curr.Microbiol.App.Sci. 7(06): 2578-2581. doi: https://doi.org/10.20546/ijcmas.2018.706.304 